\title{
A Comparative Study on Zn and Zn-Y Coatings on 42CrMo Steel by Pack Cementation Process
}

\author{
Li Liu, Sirong $Y u^{*}$ \\ College of Mechanical and Electronic Engineering, China University of Petroleum (East China), \\ Qingdao, 266580, P.R China \\ *E-mail: liuli1212006@outlook.com, liuli1212006@126.com
}

doi: $10.20964 / 2017.10 .22$

Received: 20 May 2017 / Accepted: 28 July 2017 / Published: 12 September 2017

\begin{abstract}
$\mathrm{Zn}$ and $\mathrm{Zn}-\mathrm{Y}$ coatings on $42 \mathrm{CrMo}$ steel were prepared by pack cementation process at $360^{\circ} \mathrm{C}, 370^{\circ} \mathrm{C}$, $380^{\circ} \mathrm{C}, 390^{\circ} \mathrm{C}$ and $400^{\circ} \mathrm{C}$ for $4 \mathrm{~h}$, respectively. The purpose of this work was to comparatively study the differences on the microstructure and corrosion behavior between the two coatings. The relationship between the coating thickness and the temperature followed the linear rule. The $\mathrm{Zn}$ coating was continuous and had a single-layer structure. The $\mathrm{Zn}-\mathrm{Y}$ coating exhibited a similar structure to the $\mathrm{Zn}-\mathrm{Fe}$ coating. The $\mathrm{Zn}-\mathrm{Fe}$ coating was a layer of $\mathrm{Fe}-\mathrm{Zn}$ intermetallic compounds with increasing $\mathrm{Fe}_{3} \mathrm{Zn}_{10}$ concentration. $\mathrm{YZn}_{5}$ was formed with the addition of $\mathrm{Y}$. The effect of $\mathrm{Y}$ addition on the microstructure and corrosion behavior of the $\mathrm{Zn}$ coating was discussed. The thickness of the $\mathrm{Zn}-\mathrm{Y}$ coating was thicker than that of the $\mathrm{Zn}$ coating. The activation energy for the formation of the coating decreased with the addition of $\mathrm{Y}$. The concentration of $\mathrm{Fe}_{3} \mathrm{Zn}_{10}$ phase in the $\mathrm{Zn}-\mathrm{Y}$ coating was slightly higher than that in the $\mathrm{Zn}$ coating, which suggested that the addition of $\mathrm{Y}$ promoted the formation of the $\mathrm{Fe}_{3} \mathrm{Zn}_{10}$ phase. The immersion test showed that the addition of $\mathrm{Y}$ could improve the ability of the coating to resist the penetration of $\mathrm{Cl}^{-}$and $\mathrm{O}_{2}$.
\end{abstract}

Keywords: Zn; Pack cementation; Y; Microstructure; Corrosion

\section{FULL TEXT}

(C) 2017 The Authors. Published by ESG (www.electrochemsci.org). This article is an open access article distributed under the terms and conditions of the Creative Commons Attribution license (http://creativecommons.org/licenses/by/4.0/). 